\title{
Root Cause Analysis of Project Delay in BGC-TEG Project
}

\author{
Moh. Nur Muhadi and Gatot Yudoko
}

\section{ABSTRACT}

PT WEI is a company that the main business as fabricator contractor for oil and gas and renewable energy industry located at Batam, Indonesia, they have operate for more than 15 years. The company produce types of facilities such as Process Packages module, FPSO (Floating Production Storage and Offloading) Topside Modules, E-house module and Sub-Station packages for client from all over world. The problem on this research is the delivery delay issue during execution of the BGC-TEG project. the project that have scope of EPC (Engineering Procurement and Construction) contract for delivery process module include mechanical equipment, piping and accessories for client at middle east, the delivery project delay is $\mathbf{2 1}$ months from original contract 11 months. The research to determine main factor that contribute to the delay by quantitative method, to gain information and identify alternative for improvement action. The primary data gathered from interview with some person in charge team member of the project. The secondary data gain from internal company document, project record and report, and project repository data base. Study literature of some similar case of project delay from various papers and articles reviewed. Fishbone diagram as analysis method with framework based on PMBOK by Project Management Institute to gain the root cause factors and propose solution alternative action to prevent same issue happen on future.

Keywords: EPC Contract, Fabricator, Fishbone Diagram, Project Delay.

Submitted : November 08, 2021

Published : December 05, 2021

ISSN: 2507-1076

DOI: $10.24018 /$ ejbmr.2021.6.6.1161

Moh. Nur Muhadi

School of Business and Management,

Institut Teknologi Bandung, Indonesia.

(e-mail: nur_muhadi@sbm-itb.ac.id)

Gatot Yudoko

School of Business and Management,

Institut Teknologi Bandung, Indonesia.

(e-mail: gatot ${ }^{@}$ sbm-itb.ac.id)

*Corresponding Author

\section{INTRODUCTION}

In the condition of down turn of Oil and Gas business on period of 2017-2019, PT WEI has experiencing the low season of new project incoming to yard. There are only available 2 active projects at that time, with small prospect of new coming project for first to second quarter of 2019. On this condition the sister company that operate at Middle East has got new big project from BGC at Iraq. PT WEI has been selected by the group company to execute the project at Batam yard.

PT WEI main business is as construction fabricator company for Oil and Gas industry and renewable energy industry. Some of the product and project experiences such as Process Packages module, FPSO Topside Modules, Ehouse module and Sub-Station packages. The company has been operated at Batam area for more than 15 years.

The company have start executes the BGC TEG Project of by mid of August of 2019, with contract to complete in 43 weeks or 11 months. Project team has experienced some internal and external issues or constraints along the project execution process. The external issues from client, stakeholder, consultant, vendor, supplier, and global issues of pandemic Covid-19 that destructed health and economy condition of all country. Internal issues such as lack of leadership on project management and site work, low workmanship, lack of control of quality issues etc. Finally, project experiencing delay for 21 months from original 11 months of contract. There are some impacts to the company due the project's completion delay. The customer raise complaint effect in the lowering customer level of satisfaction and not good for company reputation. Delay's project increasing project cost expenses, lead to budget over run. Morale condition of project team member reduce and increasing distrust in relationship affect by the delay. The other impact is related to vendor, supplier, consultant and other $3^{\text {rd }}$ parties will reduce the trust support next project. This research is focus in the performance evaluation of project management implementation aspect on finding and determine root cause and main factor causing the BGC-TEG project delay and to recommend the corrective action as the lesson learned for future project within the company.

The research framework of project management is accomplished through the appropriate application and integration of the project management processes identified for the project (Project Management Institute, PMBOK 2017), and several research paper on project delay issues.

The method uses in the research data gathering by conducting interviews, focus group discussion, examine available project data, and identify root cause by cause-effect or fishbone diagram. Analysis data by study literature, data analysis and mapping of lesson learn repository to propose solution alternative.

The research result can be summarize that the project delivery delay main factor from 4 main aspects that the first is Procurement management aspect such as rare of raw 
material, un-perform vendor, second document and communication management such as lateness of client approval, QA/QC and production document control system and communication channel in internal team. The third is production and quality management such as tools and equipment availability, skill and competence of worker and inspector as well as leader and supervisor. The forth aspect is project leadership in project team of supervisor, leader and project management team. Improvement of above aspect is need to improve with continue and regular action plan

\section{LITERATURE REVIEW}

The construction industry mainly in oil and gas sector, is one of the main sector the provide great support for the development of an economy of country. The project will involving great funding support, require bulk materials, engage several stakholders from many country and relate to great quantity of workforces. However, many construction project has experience extensive delays and thereby exceed the initial time and budget cost etimated. Construction delays are considered to be one factor of the project success performance measurement in term of "Triple Constraints Triangle" of time/schedule, cost/resources, and quality/scope.

There are number of the definition for delay. Delay can be define as difference in time between project completion as stated in the contract and the date of actual completion of project (Waqar, Chitrajan, 2020). To make something happen later than expected: to cause something to be performed later than planned; or to not act timely each of these definitions can be describe a delay to an activity of work in a schedule. On cinstruction project it is not uncommon for delay to occur (Trauner Jr, 2009).

Another definition is by A.A. Aibinu who defines delays as a situation where the contractor and the project owner jointly or severally contribute to the non-completion of the project within the agreed contract period. Likewise, Sanders and Eagles also define delay as an event that causes extended time to complete all or part of a project (Ahmed, 2015)

There are 5 factors causing delay in project construction study at singapore were: (1) speed of decision making by client; (2) speed of decision making involveing all project team;(3) communication/coordination between parties; (4) level of experience of consultants; and (5) difficulties on financing project by contractors (Hwang and Leang, 2013).

A study of factors that caused delay in construction project in Qatar revealed that there are seven significant rootcause are: delay in decision making, poor site management and supervision, shortage of construction materials, changes to the project by owner, shortage of labour, low productivity of labout, delays related to subcontractor's work, delay in revising and approving documents and unqualified workforce (Gunduz \& Abuhasan, 2016).

Ahmed, T. In his study has clustered these fators into four (4) factors broad categories of consultant related, contractor -related, client-related and external-related factors. Toor and Oginlana (2008) in thier study has list out the cause of the construction delays as lack of practice of project managment, different between the construction and design, insufficient system of procurement, inadequate resources, cultural issues, varied interest of stakeholders, cultural issuse and lapses in comunication.

Several effect raised of the delay issue to the project performance were: time overrun, Profit reduction for contractors, distrust wihtinn the parties, delay in the work progress payments, disputes between the owner and contractor (Shruti and Sdinish, 2014). In the survey by Sambasivan and Scon (2007), cost overrun is the highest ranking of project delay effects. Cost overrun will be the cost in excess of the estimated project cost and this excess is an inconvenience to all partiest in the construction project. Contractor experince abnormal losses and cashflow crisis, consultant will lose trust and confidence from clients in exection plan, goverment will lose taxes value money (Ahmed, 2015).

\section{Methodology}

This research author has obtained information and data from several sources by mean of primary and secondary data collection to gain the goal and objectives of the study. The data has been gathered in two phase. A literatur review was conducted concerning the research subject of delay in PT WEI fabrication project from several related project delay study. The research is conducted through quanlitative research by using interview to collect information from project manager, project engineer, construction manager, QA/QC leader, planner and supervisor. Others data collected and analysis from project record, monthly and weekly project report, project communication record, project schedule and lesson learn repository data, quality record, procurement record, client feedback and vendor delivery data and company documentation.

The problem that occurs in the company analyzed by using Cause-effect or Fishbone Diagram and supported with root cause analysis in order to find the main factor that contribute to the problem.

\section{Finding AND ARGUMENTS}

The project delay issue of as indicate by comparing original versus actual project schedule as below table I.

After indentifying process from the project data and repository, review study literatur from previous research, researcher conduct interviews and discussion with project team involved in the project focusing on the cause of delay project in the BGC-TEG project, the main 5 factors that contribute to delays have been determined as below:

\section{1) Engineering Aspect}

The factors which is related of the design changes of basis design factor by client and lateness of project documents approval by related stakeholder.

\section{2) Procurement Aspect}

The factor which is related to the root cause of the suplier/vendor non-perform and delay delivery of main equipment due to rare raw material aand also effect of pandemic Covid-19. 


\section{3) Construction aspect}

In this aspect the main source of delay is too many site rework that mostly on piping work and installation integration with mechanical equipments. This issue mainly due to lack of supervisory at site and un-perform workmanship of the worker. On the other site lack of control by QA/QC inspector during execution phase.

TABLE I: PlAN VERSUS ACTUAL PROJECT SCHEDULE

\begin{tabular}{|c|c|c|c|c|c|c|c|c|c|c|c|c|c|c|c|c|c|c|c|c|c|c|c|c|c|}
\hline \multirow{3}{*}{\multicolumn{4}{|c|}{\begin{tabular}{|c|} 
BGC-NC55 Project TEG Regeneration Unit Milestone Completion Date \& \\
Time Line
\end{tabular}}} & \multicolumn{6}{|c|}{2019} & \multicolumn{12}{|c|}{2020} & & 20 & 221 & \\
\hline & & & & & & & & 9 & 9 & & i & จ & ก & \% & i & & ก & ) & 8 & ล & ก & $\vec{\pi}$ & & & \\
\hline & & & & & & & & & $\stackrel{\circ}{\circ}$ & & & $\Sigma$ & $\frac{8}{4}$ & & 引 & इ & $\frac{3}{4}$ & & & & & & & $\sum^{\pi}$ & $\frac{\vdots}{4}$ \\
\hline Key Activities & & Schedule C & ompletion & MO & M1 & M2 & M3 & M4 & M5 & M6 & M7 & M8 & & M10 & & & & & & & & & & & M21 \\
\hline & & Act Start & Act Finish & & & & Norma & & & & & & & & & & & & & & & & & & \\
\hline Project Duration General & & 25-Jul-19 & Apr-21 & $\mathrm{x}$ & $\mathrm{x}$ & $\mathrm{x}$ & $\mathrm{x}$ & $\mathrm{x}$ & $\mathrm{x}$ & $\mathrm{x}$ & $\mathrm{x}$ & $\mathrm{x}$ & $\mathrm{x}$ & $\mathrm{x}$ & $\mathrm{x}$ & $\mathrm{x}$ & $\mathrm{x}$ & $\mathrm{x}$ & $\mathrm{x}$ & $\mathrm{x}$ & $\mathrm{x}$ & $\mathrm{x}$ & $\mathrm{x}$ & $\mathrm{x}$ & $\mathrm{x}$ \\
\hline Rebaseline After VO Finalization & & 25-Jul-19 & & $\mathrm{x}$ & & & & & & & & & & & & & & & & & & & & & \\
\hline PIM & & 17-Sep-19 & & & & $\mathrm{x}$ & & & & & & & & & & & & & & & & & & & \\
\hline 1st Cut & & 18-Sep-19 & & & & $\mathrm{x}$ & & & & & & & & & & & & & & & & & & & \\
\hline Engineering & & & & & & & & & & & & & & & & & & & & & & & & & \\
\hline \begin{tabular}{|l} 
Process Discipline \\
\end{tabular} & Plan & & Aug-19 & & $x$ & & & & & & & & & & & & & & & & & & & & \\
\hline & Actual & & Aug-19 & & $x$ & & & & & & & & & & & & & & & & & & & & \\
\hline 3D Model Review & Plan & & Oct-19 & & & & $\mathrm{x}$ & & & & & & & & & & & & & & & & & & \\
\hline & Actual & & Nov-19 & & & & & $\mathrm{x}$ & & & & & & & & & & & & & & & & & \\
\hline Piping Isometric & Plan & & Oct-19 & & & & $\mathrm{x}$ & & & & & & & & & & & & & & & & & & \\
\hline & Actual & & Nov-19 & & & & & $\mathrm{x}$ & & & & & & & & & & & & & & & & & \\
\hline Piping MTO Final & Plan & & Oct-19 & & & & $\mathrm{x}$ & & & & & & & & & & & & & & & & & & \\
\hline & Actual & & Dec-19 & & & & & & $x$ & & & & & & & & & & & & & & & & \\
\hline Piping GA & Plan & & Oct-19 & & & & $\mathrm{x}$ & & & & & & & & & & & & & & & & & & \\
\hline & Actual & & Dec-19 & & & & & & $x$ & & & & & & & & & & & & & & & & \\
\hline Structural MTO & Plan & & Sep-19 & & & $\mathrm{x}$ & & & & & & & & & & & & & & & & & & & \\
\hline & Actual & & Aug-19 & & $x$ & & & & & & & & & & & & & & & & & & & & \\
\hline Structural Framing Drawing & Plan & & Sep-19 & & & $\mathrm{x}$ & & & & & & & & & & & & & & & & & & & \\
\hline & Actual & & Oct-19 & & & & $\mathrm{x}$ & & & & & & & & & & & & & & & & & & \\
\hline Mechanical D/S \& GA & Plan & & Sep-19 & & & $x$ & & & & & & & & & & & & & & & & & & & \\
\hline & Actual & & Dec-19 & & & & & & $x$ & & & & & & & & & & & & & & & & \\
\hline Electrical D/S \& Drawing & Plan & & Oct-19 & & & & $\mathrm{x}$ & & & & & & & & & & & & & & & & & & \\
\hline & Actual & & Feb-19 & & & & & & & & $x$ & & & & & & & & & & & & & & \\
\hline Instrument D/S \& Drawing & Plan & & Nov-19 & & & & & $\mathrm{x}$ & & & & & & & & & & & & & & & & & \\
\hline & Actual & & Dec-19 & & & & & & $\mathrm{x}$ & & & & & & & & & & & & & & & & \\
\hline Procurement & & & & & & & & & & & & & & & & & & & & & & & & & \\
\hline PO\& Delivery of Steel Material & Plan & Aug-19 & Nov-19 & & $x$ & $x$ & $\mathrm{x}$ & $\mathrm{x}$ & & & & & & & & & & & & & & & & & \\
\hline & Actual & Aug-19 & Nov-19 & & $x$ & $x$ & $\mathrm{x}$ & $\mathrm{x}$ & & & & & & & & & & & & & & & & & \\
\hline PO\& Delivery of Piping Material & Plan & Aug-19 & Feb-20 & & $\mathrm{x}$ & $\mathrm{x}$ & $\mathrm{x}$ & $\mathrm{x}$ & $x$ & $x$ & $\mathrm{x}$ & & & & & & & & & & & & & & \\
\hline & Actual & Sep-19 & Jul-20 & & & $x$ & $x$ & $x$ & $x$ & $x$ & $\mathrm{x}$ & $\mathrm{x}$ & $\mathrm{x}$ & $\mathrm{x}$ & $x$ & $\mathrm{x}$ & & - & & & & & & & \\
\hline PO\& Delivery of Mechanical Material & Plan & Aug-19 & Feb-20 & & $x$ & $\mathrm{x}$ & $\mathrm{x}$ & $\mathrm{x}$ & $\mathrm{x}$ & $x$ & $\mathrm{x}$ & & & & & & & & & & & & & & \\
\hline & Actual & Aug-19 & Dec & & $x$ & $\mathrm{x}$ & $\mathrm{x}$ & $x$ & $x$ & $x$ & $x$ & $x$ & $\mathrm{x}$ & $\mathrm{x}$ & $\mathrm{x}$ & $\mathrm{x}$ & $\mathrm{x}$ & $x$ & $x$ & $\bar{x}$ & $\bar{x}$ & & & & \\
\hline PO\& Delivery of Instrument Material & Plan & Sep-19 & Mar-20 & & & $\mathrm{x}$ & $\mathrm{x}$ & $\mathrm{x}$ & $x$ & $x$ & $\mathrm{x}$ & $\mathrm{x}$ & & & & & & - & & & & & & & \\
\hline & Actual & Sep-19 & Nov-20 & & & $x$ & $\mathrm{x}$ & $\mathrm{x}$ & $x$ & $x$ & $\mathrm{x}$ & $x$ & $\mathrm{x}$ & $x$ & $\mathrm{x}$ & $\mathrm{x}$ & $\mathrm{x}$ & $\mathrm{x}$ & $\mathrm{x}$ & $x$ & & & & & \\
\hline PO\& Delivery of Eletrical Material & Plan & Sep-19 & Jan-20 & & & $x$ & $x$ & $x$ & $x$ & $x$ & & & & & & & & & & & & & & & \\
\hline & Actual & Sep-19 & Feb-20 & & & $x$ & $x$ & $x$ & $x$ & $x$ & $x$ & & & & & & & & & & & & & & \\
\hline Construction & & & & & & & & & & & & & & & & & & & & & & & & & \\
\hline Structure FAB \& Erection Work & Plan & Oct-19 & Feb-20 & & & & $x$ & $x$ & $x$ & $x$ & $x$ & & & & & & & & & & & & & & \\
\hline & Actual & Sep-19 & Aug-20 & & & $x$ & $\mathrm{x}$ & $x$ & $x$ & $x$ & $\mathrm{x}$ & $x$ & $\mathrm{x}$ & $\mathrm{x}$ & $\mathrm{x}$ & $\mathrm{x}$ & $\mathrm{x}$ & & & & & & & & \\
\hline Pressure Vessel Fabrication Work & Plan & & $\mathrm{Ja}$ & & $x$ & $x$ & $x$ & $\mathrm{x}$ & $x$ & $x$ & & & & & & & & & & & & & & & \\
\hline & Actual & 0 & 20 & & & & $x$ & $\mathrm{x}$ & $x$ & $x$ & $x$ & $\mathrm{x}$ & $x$ & $x$ & $\mathrm{x}$ & & & & & & & & & & \\
\hline Piping Fabrication Work & Plan & $\mathrm{Oc}$ & Apr-20 & & & & $\mathrm{x}$ & $x$ & $\mathrm{x}$ & $x$ & $\mathrm{x}$ & $x$ & $\mathrm{x}$ & & & & & & & & & & & & \\
\hline & Actual & $\mathrm{D}$ & $\pi$ & & & & & & $\mathrm{x}$ & $x$ & $x$ & $x$ & $\mathrm{x}$ & $x$ & $\mathrm{x}$ & $\mathrm{x}$ & & & & & & & & & \\
\hline Blast \& Paint Main Structure & Plan & 19 & Dec-19 & & & & & $x$ & $x$ & & & & & & & & & & & & & & & & \\
\hline & Actual & & & & & & & $x$ & $x$ & $x$ & $x$ & $x$ & $x$ & $\mathrm{x}$ & $x$ & $\mathrm{x}$ & $\mathrm{x}$ & & & & & & & & \\
\hline Piping Installation Work & Plan & Oct-19 & Apr-20 & & & & $\mathrm{x}$ & $\mathrm{x}$ & $\mathrm{x}$ & $x$ & $\mathrm{x}$ & $\mathrm{x}$ & $\mathrm{x}$ & & & & & & & & & & & & \\
\hline & Actual & Ja & Feb-21 & & & & & & & $x$ & $x$ & $x$ & $\bar{x}$ & $x$ & $\mathrm{x}$ & $\mathrm{x}$ & $\mathrm{x}$ & $x$ & $x$ & $x$ & $\mathrm{x}$ & $x$ & $\mathrm{x}$ & & \\
\hline E\&I Installation Work & Plan & 0 & $\mathrm{Alt}_{\mathrm{t}}$ & & & & $\mathrm{x}$ & $x$ & $x$ & $x$ & $x$ & $x$ & $x$ & & & & & & & & & & & & \\
\hline & Actual & Mar-20 & Jan-21 & & & & & & & & & $\mathrm{x}$ & $x$ & $\mathrm{x}$ & $\mathrm{x}$ & $\mathrm{x}$ & $\mathrm{x}$ & $\mathrm{x}$ & $\mathrm{x}$ & $x$ & $x$ & $x$ & & & \\
\hline Hydrotest Work & Plan & Feb-20 & Apr-20 & & & & & & & & $x$ & $x$ & $x$ & & & & & & & & & & & & \\
\hline & Actual & $\mathrm{Ja}$ & $\mathrm{M}$ & & & & & & & $x$ & $x$ & $x$ & $\bar{x}$ & $x$ & $\mathrm{x}$ & $\mathrm{x}$ & $\mathrm{x}$ & $x$ & $\mathrm{x}$ & $\mathrm{x}$ & $x$ & $x$ & $x$ & $\mathrm{x}$ & \\
\hline Reinstatement Work & Plan & Mar-20 & Apr-20 & & & & & & & & & $\mathrm{x}$ & $\mathrm{x}$ & & & & & & & & & & & & \\
\hline & Actual & Feb-20 & Mar-21 & & & & & & & & $x$ & $x$ & $x$ & $\mathrm{x}$ & $\mathrm{x}$ & $x$ & $\mathrm{x}$ & $x$ & $x$ & $\mathrm{x}$ & $\mathrm{x}$ & $x$ & $x$ & $x$ & \\
\hline IFAT Work for Lighting Power & Plan & & $A_{l}$ & & & & & & & & & $\mathrm{x}$ & $\mathrm{x}$ & & & & & & & & & & & & \\
\hline & Actual & Dec-20 & Jan-21 & & & & & & & & & & & & & & & & & & $\mathrm{x}$ & $x$ & & & \\
\hline \begin{tabular}{|l} 
Dismantling Skid Wise \\
\end{tabular} & Plan & Mar-20 & May-20 & & & & & & & & & $x$ & $\mathrm{x}$ & $\mathrm{x}$ & & & & & & & & & & & \\
\hline & Actual & Jan-21 & $\mathrm{M}$ & & & & & & & & & & & & & & & & & & & $x$ & $x$ & $\mathrm{x}$ & \\
\hline Preservation Work & Plan & May-20 & May-20 & & & & & & & & & & & $\mathrm{x}$ & & & & & & & & & & & \\
\hline & Actual & Mar-21 & Mar-02 & & & & & & & & & & & & & & & & & & & & & $x$ & \\
\hline Loadout (Ex-Work) & Plan & May-20 & May-20 & & & & & & & & & & & $\mathrm{x}$ & & & & & & & & & & & \\
\hline & Actual & Apr-21 & Apr-21 & & & & & & & & & & & & & & & & & & & & & & $x$ \\
\hline
\end{tabular}

(Source: Author, 2021).

\section{4) Project Management Aspect}

Project management lack of leadership contribute as main root cause and the further effect of many turnover of the project management team.

\section{5) Client Related Aspect}

Support of client site personel lack of team member and competence on site work contribute to the delay as well.
However, by using the Cause effect - Fishbone diagram Fig. 1, these aspects has clasified into five groups. The fishbone diagram could give a comprehensive views of understanding of these cause the tools usefull for solving interconnected issues ( Wealleans, 2017). It is a technique for organizing a groupd's thoughts to set the issues's main drivers. It can be utilized to decide and comprehend the associations among cause and effect of each issues. 
Analysis from above 5 aspects of the root causes that contribute to the project delay, it could categorized in two based on the controllability. The controllable root cause is the root cause which the company or project team can take action to mitigate or minimize the effect to the project. On this category include engineering aspect of lateness of documentation approval. In procurement aspect the rare project raw material and un-performance of vendor or subcontractor. In construction aspect too many rework of piping work and lack of QA/QC control in production work. In project management aspect is lack of leadership and highly team turnover.

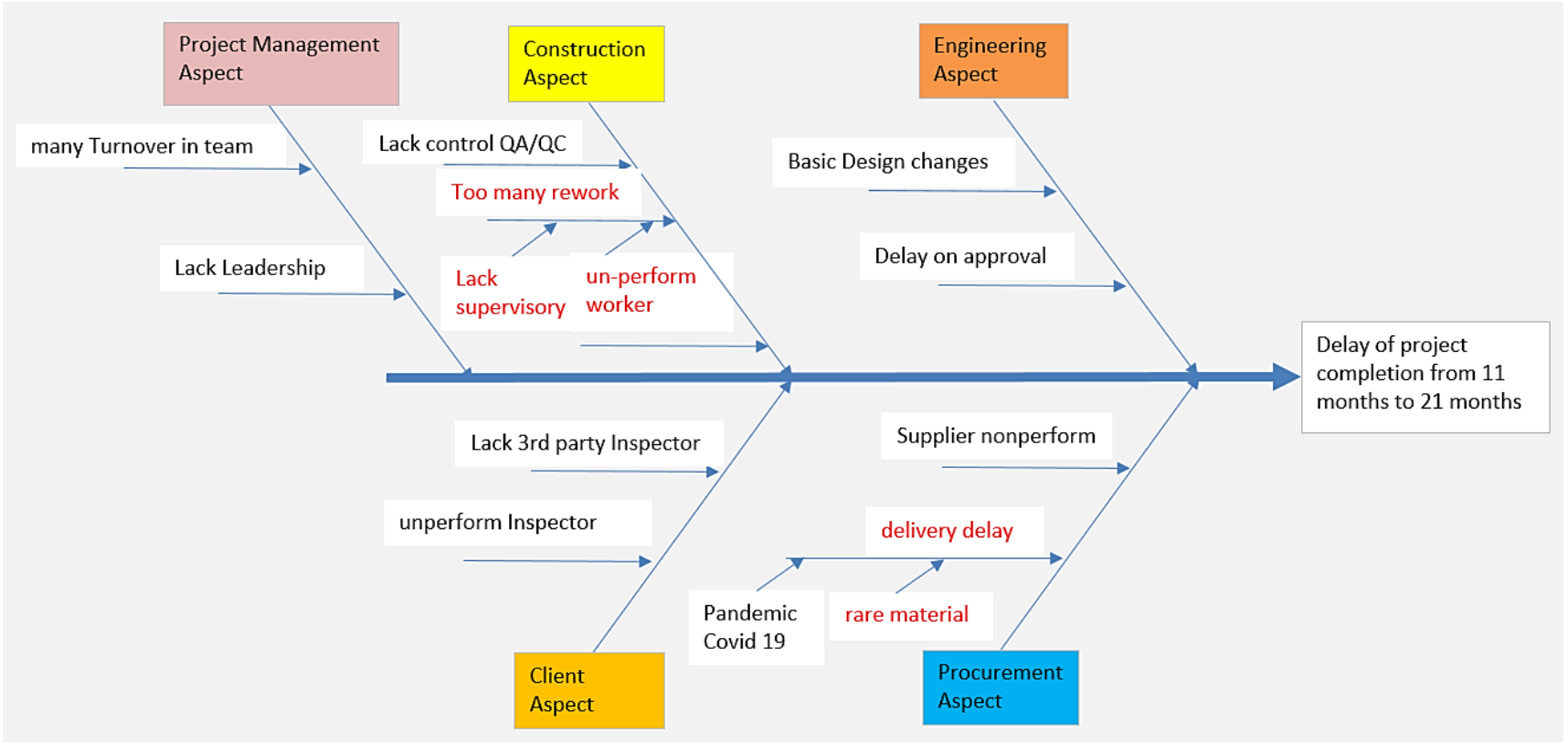

Fig. 1. Fishbone Diagram. (Source: Author, 2021).

Second category is uncontrollable root cause, the root cause that the company or project team authorization cannot eliminate the root cause effect to the project delays. In this category include engineering aspect of design basic changes by project owner. In procurement aspect relate the pandemic Covid-19 effect to delay the material delivery. In client related aspect is the lack of client inspector at site and inspector unperformed or incompetence to support the work in site.

\section{CONCLUSIONS}

In the BGC-TEG project construction, there are several factor as root cause of delivery delay in project performance. The client related aspect such engineering design changes, client site team and pandemic Covid-19 became the uncontrollable factor that contribute to the major delay and time overrun. Yet, lack of leadership project management, coordination and collaboration in the team member, as well as lack of quality and production site control as controllable factor that can be improve with proper coordination and better communication as well as documentation system. Procurement management system in order for vendor/subcontractor selection and material supplier to be improved.

For future research, it is recommended to study to build and integration of vendor selection system which is integrated with existing SAP system in order for all related department could participate in selection process to get the best vendor. Vendor performance measurement system to be developed a dashboard that present all performance variable can be monitored by all stakeholder for better control and faster action respond minimize miss-performance. Upgrade documentation system and server data base which is allow project manager and stakeholder for access through application at everywhere to monitor and control.

In order improving communication line system for internal production team, it is to create daily activity reporting system that easier and simple for production site personnel. Upgrading tools, proper inspection method, and more training session for worker and inspector competence as well as company culture will improve workmanship and quality of product.

The last is to improve in leadership of all project team, supervisor, and leader at QA/QC team, production team as well as project management team. Effective leadership in the team will drive work in better pace and quality. Improvement activity to establish training program with the main purpose to create team collaboration, effective communication and better understanding in the project execution process. Project collaboration, effective communication and understanding of all team member by providing regular leadership training program will minimize gap of site issues.

\section{REFERENCES}

Ahmed, T, Delay in construction project (2015). The American University of Iraq, Sulaimani.

Al-Adwani, M.M., Mollasalehi, S. \& Fleming, A.J. (2018). A Study of root causes of delays in the public-sector construction project in Kuwait, University of Salford Manchester.

Fanousse, M.I. (2017). Cause of Delay in construction Project in Oil and Gas Construction Industry, The British University in Dubai.

Hwang B.G, Leong, L.P. (2013). Comparison of schedule delay and causal factors between traditional and green construction projects. Technological and Economic Development of Economy, 19(2), 310330.

Hamzah, N., Khoiry, M.A., Arshad, I., Tawil, N.M., \& Che Ani, A.I.(2011), Cause of Construction Delay - Theoritical Famework, The National 
European Journal of Business and Management Research www.ejbmr.org

University of Malaysia.

Paray, W.A, Kumar, C. (2020). Delay Analysis in construction project; IRJET (07).

Project Management Institute. A guide to the Project Management Body of Knowledge (PMBOK 2017) $6^{\text {th }}$ ed.

Seno, G.W., Firman, A.S. (2018). Analysis of critical factors causing project closeout delay at PT Gas Mandiri, IJBA. 7(2), 1-3.

Trauner Jr, T.J. Book (Construction Delay: Understanding them clearly, analyzing them correctly) $2^{\text {nd }}$ edition (2009).

Wealleans, D. (2017). The organizational Measurement Manual, Taylor \& Francis.

Zarei, B, Sharifi H, \& Chagouee Y. (2017). Delay Cause Analysis in complex construction project; a semantic Network Analysis Approach University of Liverpool. 